\title{
Polyglot Translators: Chinese, Dutch, and Japanese in the Introduction of Western Learning in Tokugawa Japan
}

\author{
Martin J. Heijdra
}

The life of an area studies librarian is not always excitement. Yes, one enjoys informing bright graduate students of the latest scholarship, identifying Chinese rubbings of Egyptological stelae, or discussing publishing gaps in the current scholarship with knowledgeable editors; but it involves sometimes the mundane, such as reshelving a copy of a nineteenth-century Japanese translation of a medical work by Johannes de Gorter. ${ }^{1}$

It was while performing the latter duty that I noticed something odd. The characters used to write Gorter were 我爾德兒, which indeed could be read as Gorter. That is, if read in modern Chinese; if read in the usual Sino-Japanese, it would be *Gajitokuji, something far from the Dutch pronunciation. A quick perusal of some scholars of rangaku 蘭學, “Dutch Studies,” revealed a general lack of awareness of this question, why a Dutch name in a nineteenth-century Japanese book would be read in modern Chinese. Prompted to write an article in honor of a Dutch editor of East and South Asian Studies, I decided to investigate this more thoroughly. There are many aspects to consider, and I must confess that the final reason is hard to come by; but while I have not reached a final conclusion, I hope that in the future scholars will at least recognize the phenomenon when encountered.

The issue turned out to be difficult to investigate, and it is instructive to first discuss why.

First, let's blame librarians and bibliographers. They, in modern reference works and catalogues, are very helpful in identifying the same author behind the various ways original works refer to them, generally to the benefit of the user. They call this the authorized form of an author. Thus, Johannes de Gorter in Western catalogues, or Goruteru, in katakana, in Japanese ones. Beneficial,

1 The Princeton edition I used is Johannes de Gorter, Zōho jūtei naika sen'yō 増補重訂内科撰 要, tr. Udagawa Genzui 宇田川玄随 et al. (Edo: Suharaya Ihachi, after 1822), a translation of Gezuiverde geneeskonst, 1761. 
except for when one wants to investigate which exact characters were used originally....

Blame even more the scholars. There exists a widespread division between those scholars investigating the place of Chinese thought in Tokugawa Japan and those scholars investigating Dutch or Western learning. The former do not know Dutch, the latter often consider any sign of Chinese influence an indicator of sadly incomplete replacement by Western thought; they rarely talk to each other.

Finally, let's blame the editors. They often have modern scholars rewrite original texts so that current readers can easily follow such texts; therefore, someone for whom the main object of study is exactly the original format is out of luck. To give a hypothetical Western example: it is sometimes difficult to decide what is a given, and what is a family name, and one possible solution is to write the family name in capitals: Paul KROLL or Stephen TEISER (for an example, see the Contents Table in East Asian Publishing and Society). Now imagine we want to investigate the history of this solution. Library catalogues, scholarly bibliographies, or specialized monographs rarely maintain such a distinction: one will have to go back to the original work. The possible gap between the originally printed format and the text as spelled out in a modern monograph is especially large in Japanese because much writing was done in a Japanese version of Classical Chinese. I must beg the reader's forgiveness to try to explain, in however simplified a manner, the complicated way a Japanese reader approaches such a text, called kanbun 漢文. ${ }^{2}$

One method was to mark the original characters with special small, secondary marks called kaeriten 返り点, telling the reader how to change the original word order, and where to put in particles or verb endings. By juggling the sentence around according to those signs, a rather stiff resemblance to a proper sentence in Japanese results. Alternatively, one could spell out the resulting Japanese sentence, which I call here for simplicity's sake the kundoku 訓読 method. The original Chinese characters would be pronounced either in Chinese adjusted to the Japanese phonetic system (Sino-Japanese, hereafter SJ ), or in "pure" Japanese (hereafter J) using a standardized Japanese translation. Thus the word kanbun itself is SJ. When considered helpful, such SJ or J pronunciations were written in small kana syllables next to the character, which is called furigana 振り仮名. Currently sJ usually uses the angular katakana script, pure Japanese the round hiragana script, and the small syllables are to

2 In order to stress the separation from any spoken Chinese form, current scholars often use the term "Sinitic" instead of Classical Chinese. See, e.g., Peter F. Kornicki, Languages, Scripts, and Chinese Texts in East Asia (Oxford: Oxford Univ. Press, 2018). 
the right of the character. In Tokugawa times, katakana was the usual form for all cases, and could be to either side of the character. And the "pronunciation" could almost imperceptibly verge into explanations rather than pronunciations. Thus, the word usually read as sommokufu 草木譜, “botanical treatise," when it was used in the translated title of an early Dutch imported book into Japan, had in furigana the Dutch word kuroitobukku, Kruidboek. ${ }^{3}$

And finally, let's blame the printers. Although Japan has a printing environment that at least in principle could faithfully reproduce the original formats, a Western author rarely has such options. Efforts to escape the difficulty often force one to choose an explicit reading that a Japanese reader may not have made. Thus, using a modern pinyin transliteration in a Japanese context for a title "really" written in Chinese may give the wrong impression that a Japanese reader would have known Chinese pronunciation.

Unlike what the division among modern scholars could imply, China and Holland (the term I will use here) were not always separated that clearly in Tokugawa Japan. ${ }^{4}$ Both were seen as exotic, and fulfilled the role of the "other" that gradually also resulted in a higher appreciation for the "Japaneseness" of Japan. What is especially important to realize is that there existed an influence of Western studies on Japan through Chinese works translated by Jesuit writers predating any Dutch rangaku influence. ${ }^{5}$ A Dutch interpreter such as Nishikawa Joken 西川如見 (1648-1724) could write on both China (the work Ka'i $t s \bar{s} s h \bar{o} k \bar{o}$ 華夷通商攻, “A Study of the Commercial Intercourse with the Chinese and Other Foreigners") and Holland (Nagasakiyawagusa 長崎夜話草, "Twilight tales of Nagasaki.") ${ }^{6}$

3 For the introduction into Japan of this 1554 Cruydt-boeck of Dodoens, see the articles in Dodonaeus in Japan: Translation and the Scientific Mind in Tokugawa Japan, ed. W. F. Vande Walle (Leuven: Leuven Univ. Press, 20o1), and Federico Marcon, The Knowledge of Nature and the Nature of Knowledge in Early Modern Japan (Chicago: Univ. of Chicago Press, 2015). For furigana, see Konno Shinji, 今野真二, Furigana no rekishi 振仮名の歴史 (Tokyo: Shūeisha, 2009).

4 See, for a few attempts to interlink the study of the two, Marius B. Jansen, China in the Tokugawa World (Cambridge, Mass.: Harvard Univ. Press, 1992), and Okada Kesao 岡田袈裟 男, Edo igengo sesshoku: Rango, Tōwa to kindai Nihongo 江戶異言語接触 : 蘭語 ・唐話と 近代日本語 (Tokyo: Kasama Shoin, 20o6).

5 A few hundred such works must have been translated in the seventeenth century, see W. F. Vande Walle, "Linguistics and Translation in Pre-modern Japan and China: A Comparison," in Dodonaeus in Japan, 123-47.

6 Goodman calls Joken probably the first popularizer in Japan of European scholarship: Grant K. Goodman, Japan and the Dutch 1600-1853 (Richmond: Curzon Press, 2000), 93. This is a revised version of Goodman, The Dutch Impact on Japan, 1640-1853 (Leiden: Brill, 1967). 
To answer the Gorter-in-Chinese question we will need to ask first, to what extent did Tokugawa Japanese know Modern Chinese? There certainly was a great interest in novels written in baihua 白話, a Chinese written style closer to, but not equivalent to, spoken Chinese. Those novels were, however, rarely read using modern Chinese pronunciation, although the increased interest in reading "vernacular" Chinese novels is often wrongly assumed to also be true for the interest in modern Chinese as an oral language. ${ }^{7}$ Studies on so-called modern Chinese in the Tokugawa period, therefore, usually treat only the reception and occasionally, surprisingly, production of baihua-style novels. ${ }^{8}$

True, there was some real knowledge of spoken Chinese in Tokugawa Japan, closely linked with the Ōbaku 黃檗 (Chinese [hereafter, C] Huangbo) Zen sect. The sect had entered Japan early in the seventeenth century through Yinyuan Longqi 隱元隆琦 (1592-1673), because of the demand of the Chinese resident population in Nagasaki, largely composed of Ming exiles. The bakufu 幕府 recruited its official group of Chinese interpreters from these circles; close to two thousand members would be officially listed as interpreters until the end of the Tokugawa period, although the number of real appointees seems to have been only half that number. ${ }^{9}$

Originally the interpreters were divided into speakers of the Fuzhou, Zhangzhou, and Nanjing dialects, each linked with their own temple. ${ }^{10}$ But while those dialectical divisions remained on paper, in fact all interpreters started to learn Southern Guanhua 官話, Mandarin, that is, largely Nanjing dialect

By conflating the two under such unifying terms as "vernacular Chinese" or "vernacularization," one can easily be led astray, as is Clements in her study on translation, Rebekah Clements, A Cultural History of Translation in Early Modern Japan (Cambridge: Cambridge Univ. Press, 2015). That those baihua novels were read in straight kanbun or kundoku style is shown by Kawashima Yūko 川島優子, "Hakuwa shōsetsu wa dō yomerareta ka 白話小説はどう読められたか,” in Zoku “Kundoku” ron 続「訓読」論: 東アジア 漢文世界の形成, ed. Nakamura Shunsaku 中村春作 et al. (Tokyo: Bensei shuppan, 2010), 311-38. In the teaching material she uses, modern Chinese pronunciations were only given when homonyms explain the use of certain wrong or aberrant characters.

8 In Japanese, Okumura Kayoko 奥村佳代子, Edo jidai no Tōwa ni kansuru kiso kenkyū 江戶時代の唐話に関する基礎咑究 (Suita-shi : Kansai Daigaku Shuppanka, 2007), or the classic Ishizaki Matazō 石崎又造, Kinsei Nihon ni okeru Shina zokugo bungakushi 近世日本に於ける支那俗語文學史 (Tokyo: Kōbundō Shobō, 1940). In English, Emanuel Pastreich, The Observable Mundane: Vernacular Chinese and the Emergence of a Literary Discourse on Popular Narrative in Edo Japan (Seoul: Seoul Univ. Press, 2011).

9 Ishizaki, Shina zokugo bungakushi, 24-25.

10 Ibid., 15-19. 
deprived of its purely Nanjing characteristics (much as current Mandarin, $p u$ tonghua 普通話, is Beijing dialect without the purely Beijing characteristics). ${ }^{11}$

Ogyū Sorai 荻生徂徠 (1666-1728) may be the best-known author who paid attention to the pronunciation of modern Chinese. He took up spoken Chinese from Chinese Ōbaku monks, and insisted famously that Chinese had to be treated as a foreign language, and needed to be read using its own pronunciation, without any kanbun-related reorganization. For him, the kanbun tradition was a predigested interpretation while the reader should instead have a direct relationship with the original. ${ }^{2}$ Yet, the passage in which he thus exhorts his fellow scholars is very much written in kanbun, without even the assistance of any furigana, as was an extant exchange in spoken Chinese between Sorai and the Ōbaku monk Yuefeng 悅峰 (1655-1734), also noted down in kanbun with kaeriten. ${ }^{13}$ (Sorai was much less well-disposed to Dutch: "in lands like Holland, in which human nature differs from the normal, there are indeed languages which are difficult to understand; they are like birds calling and animals roaring; they do not approximate human feelings. But when it comes to China and Japan, all things are similar.") $)^{14}$

Sorai would form a school in which especially Okajima Kanzan 岡島冠山 (1674-1728), who had started his career as a professional Dutch translator, stood out. This Kanzan, the foremost scholar of modern Chinese as a separate language after Sorai, created no less than six modern Chinese vocabularies. Yet, aside from some of the vocabulary entries themselves, texts such as prefaces

11 Kizu Yūko 木津祐子, “Tōtsūji no ‘kanwa' jūyō 唐通事の「官話」受容,” in Zoku “Kundoku" ron, 26o-9o, points out that the interpreters were well aware of the differences between Guanhua and baihua, and studied the former. W. South Coblin has investigated the status of Guanhua during Ming and Qing times in several studies; see especially Modern Chinese Phonology: From Guānhuà to Mandarin (Paris: École des hautes études en sciences sociales, 2007). He shows how the Nanjing-based Guanhua changed slowly after the move to Beijing through the influence of Northern speakers.

Emanuel Pastreich, "Grappling with Chinese Writing as a Material Language: Ogyū Sorai's Yakubunsentei," Harvard Journal of Asiatic Studies 61 (2001): 119-70.

Text in Ishizaki, Shina zokugo bungakushi, $56-61$. Tao Demin gives an interesting overview of the discussion on how to teach Classical Chinese since Ogyū Sorai, and an explanation why kundoku rather than "direct reading” persisted. Tao Demin 陶徳民, “Kindai ni okeru 'kanbun chokudoku' ron no yuisho to yukikata近代における「漢文直読」論の由緒 と行方," in “Kundoku” ron: Higashi Ajia kanbun sekai to Nihongo 「訓読」論: 東アジア 漢文世界と日本語, ed. Nakamura Shunsaku 中村春作 et al. (Tokyo: Bensei Shuppan, 2008), 49-85.

14 Richard H. Minear, "Ogyū Sorai's Instructions for Students: A Translation and Commentary," Harvard Journal of Asiatic Studies 36 (1976): 65. 
are also in kanbun..$^{15}$ But by the time the movement was more widely taken up by the later followers of Itō Jinsai 伊藤仁齋 (1627-1705), the learning of modern Chinese pronunciation was already thought unattainable. ${ }^{16}$

Dutch, of course, was known even less. Originally, the Dutch had relied upon Portuguese in their dealings with the Japanese, and Dutch only gradually eclipsed Portuguese among the hereditary Nagasaki interpreter families which had been appointed by the bakufu. ${ }^{17}$ By later years, there might have annually been 100-150 Dutch interpreters. Outside these interpreter circles, learning Dutch was forbidden, but by 1720 the possibility of studying Dutch from the Nagasaki interpreters was permitted, and works useful toward such study began to appear openly. The Edo scholar Ōtsuki Gentaku 大槻玄澤 (1757-1827), whom we will encounter again shortly, went to Nagasaki to learn from such famous translators as Motoki Ryōei (or Yoshinaga) 本木良永 $\left(1735^{-1794)}\right.$ ), Yoshio Kōgyū 吉雄耕牛 (1720-1800), a Dutch interpreter well versed in many disciplines, and Ishii Tsuneemon 石井恒右衛門 (1743-?). ${ }^{18}$ It is important to emphasize these contributions by the Nagasaki interpreters, since for a long time the word rangaku came to be associated not with the works by those interpreters, but with the Edo scholars only, who adopted and printed scientific works in medicine, physics, botany, pharmacy, and chemistry. ${ }^{19}$ The 1774 work Kaitai shinsho 解體新書 (hereafter, Ks), “New Book on Anatomy,” translated by a group around Sugita Genpaku 杉田玄白 (1733-1817) in Edo, is thus often taken as the beginning of the scholarly rangaku field, although much of that impression is based upon a partly purposefully, partly accidentally biased overview by Sugita himself called the Rangaku shiji 蘭學事始, better known as

15 Okada, Edo igengo sesshoku, 246, finds sixty-two "modern Chinese" dictionaries published in Tokugawa times, including guides to read the baihua novels, of which only twenty-two had modern Chinese in furigana (hereafter, $\mathrm{MCK}$ ) in part or in total. Pastreich, The Observable Mundane 163, 175.

17 For the Dutch-Japanese relations in general, see the articles in Bewogen betrekkingen: 400 jaar Nederland-Japan, ed. Leonard Blussé et al. (Hilversum: Teleac, 20oo).

18 For more on the hereditary translator families, see Katagiri Kazuo 片桐一男, Oranda tsüji no kenkyū 阿蘭陀通詞の研究 (Tokyo: Yoshikawa Kōbunkan, 1985), and Sugimoto Tsutomu杉本つとむ, Nagasaki tsūji monogatari:kotoba to bunka no hon'yakusha 長崎通詞 物語 : ことばと文化の翻訳者 (Tokyo: Sōtakusha, 1990). The word tsüji, "interpreter" is, strangely, written differently for Chinese (tsüji 通事) and for Dutch translators, 通詞; ji for the Chinese means "things," that for the Dutch translators "words." For a discussion, see Ishizaki, Shina zokugo bungakushi, 2 .

19 For rangaku studies, see Numata Jirō, Western Learning: A Short History of the Study of Western Science in Early Modern Japan, tr. R.C.J. Bachofner (Tokyo: Japan-Netherlands Institute, 1992), Goodman, Japan and the Dutch, and Clements, Cultural History of Translation. 
Rangaku kotohajime. ${ }^{20}$ The Edo scholars were of a socially much higher standing than the interpreters, but the largely held perception that the latter did not have any interest in translating scientific works is just plain wrong. ${ }^{21}$

Translators faced several issues when confronted with an unknown Western term or concept, and in various different works a remarkably similar tripartite strategy was sought. One could use an existing word as a translation; create a calque or plain neologism, using characters for their semantic value; or, finally, one could use characters (or occasionally kana) for their phonetic value, with which we arrive closer to the topic of this article. ${ }^{22}$

What do I mean here by calque? A calque is a translation of a compound or phrase, whereby each part is individually translated, resulting in a special kind of neologism. Calques were created quite early. Motoki Ryōi used them already around 1682 in his Oranda Zenku Bungōzu. For the twaalfvingerige darm (duodenum, lit. "twelve-finger intestine") he used yubijüni haba no chō指十二幅腸, and for the blinde darm (cecum, lit. "blind intestine," i.e., without opening) he created mōmokuchō 盲目腸. ${ }^{23}$ Another such calque was trommelvlies (mem-

20 Shiji seems to be original sJ reading; kotohajime would be pure Japanese; without original furigana, it would be difficult to decide; see Sugimoto Tsutomu 杉本つとむ, Edo yōgaku jijō 江戶洋学事情 (Tokyo: Yasaka Shobō, 199o). For a translation, Sugita Genpaku, Dawn of Western Science in Japan: Rangaku kotohajime, tr. Ryōzō Matsumoto (Tokyo: Hokuseido, 1969). The book was written before 1815 , but remained in manuscript, and was only published in 1869 .

21 See especially Sugimoto, Edo yōgakujijō. One of such much earlier translations by a Nagasaki interpreter is Motoki Ryōi's 本木良意 Oranda zenshu naigai bungōzu 和蘭全躯内 外分合図, a translation of a 1667 work by Johann Remmelin, Pinax microcosmographicus. Translated in 1682, it was only printed in 1772. This Motoki family, hereditary Dutch translators, to whom also Motoki Ryōei, already mentioned above, belonged, is also the family of Motoki Shōzō 本木昌造, about whom I have written previously as being the introducer of modern Western type and typography in Japan: see Martin J. Heijdra, "The Development of Modern Typography in East Asia, 1850-200o," The East Asian Library Journal 11.2 (2004): 100-68. The Motoki family is special for researchers, since its family records are still intact, and therefore a figure such as Motoki Ryōei can be vividly brought to light, as was done in a 1998 exhibition in Kobe; see Nichi-Ran kōryū no kakebashi: Oranda tsūji ga mita sekai 日蘭交流のかけ橋: 阿蘭陀通詞がみた世界, ed. Kōbe shiritsu hakubutsukan 神戸市立博物館 (Kobe: Kōbeshi supōtsu kyōiku kōsha, 1998).

22 Seian Tatebe 清庵建部 and Sugita Genpaku 杉田玄白, Oranda iji mondō 和蘭醫事問 答 (Edo: Suharaya Zengorō, 1795), call the three solutions taiyaku 對譯, giyaku 義譯, and chokuyaku 直譯 (Sugimoto Tsutomu 杉本つとむ, Kokugogaku to Rangogaku国語学と 蘭語学 [Tokyo: Musashino Shoin, 1991], 377), while Motoki Ryōei uses honyaku 翻譯, giyaku, and chokuyaku. See Sugimoto, Nagasaki tsūji monogatari, 136-44, and Vande Walle, "Linguistics and Translation in Pre-modern Japan and China," 134-41.

23 Sugimoto, Nagasaki tsūji monogatari, 100-105. Sugita Genpaku and his Ks group did not much use these translations, rather inexcusable for Gentaku, who actually personally did meet with the interpreters. 
brana tympana, lit. "drum-skin") which he translated syllable by syllable as komaku 鼓膜, a word still in use. Such Japanese-inspired calques would also move into Chinese, largely after $1905 .{ }^{24}$

Now, for us, the most interesting principle is the third, phonetic one. It is here that the relationship to modern Chinese rather than to sJ becomes most visible, whether through accompanying furigana or not. ${ }^{25}$ Thus, the post- 1828 Shintei zōho Oranda yakkyō 新訂增補和蘭藥鏡, "Newly Revised Dutch Pharmaceutical Mirror" ${ }^{26}$ has MCK ipekakoana乙百葛格安 for ipecacuanha, with C yibaigegeanna closer than SJ *ippakukokkakuanna; or MCK Reiden 戻鄧 for Leiden, with C leideng rather than sJ ${ }^{*}$ Reitō. It also has the interesting MCK shike-uruboiku 失苟兒陪苦 for suikerbuik (diabetes, "sugar belly"), with C shigourpeiku, rather than sj *shikköjibaiku. In addition to Dutch, Latin was also sometimes involved. The 1837 Oranda Yōyaku benran 和蘭用藥便覽, “Easy Guide to Dutch Pharmaceutical Drugs," ${ }^{27}$ has Chinese character entries, with to the right in katakana the Latin, and to the left in katakana the Dutch name. A "vomit-wine-stone" 吐酒石 has MCK tarutarisu wemechikisu for the Latin (tartaris emeticus), and Мск burākuweinstewen for the Dutch, braakwijnsteen.

Finally, an interesting example where a calque and phonetic loan have been combined, is the word pijnappelklier, written in the Oranda iji mondō as tsükakiriru 痛果機里兒, in which pijn, "pain," is rendered as tsū 痛; appel, "fruit," as ka 果; and kiriru, "gland," as мск kilir (not sJ *kiriji.) A good example, were it not that the pijn- in pijnappel really refers to the shape of a pine-cone, not to pain at all.

Thus, modern Chinese, usually explained by furigana, was used for many such phonetic loans, and not only for the names of authors. One of the few scholars who has pointed out that modern Chinese was used for such transcriptions is, not surprisingly, a Dutch sinologist, Koos Kuiper, in a study where he traces Dutch loanwords and loan-translations in Modern Chinese by way of

24 Koos Kuiper, "Dutch Loan-Words and Loan-Translations in Modern Chinese: An Example of Successful Sinification by way of Japan," in Words from the West: Western Texts in Chinese Literary Context: Essays to Honor Erik Zürcher on his Sixty-fifth Birthday, ed. Lloyd Haft (Leiden: Centre of Non-Western Studies, 1993), 135 .

25 Motoki Ryōei is said to have even made a table of such Chinese characters corresponding to Dutch syllables, based upon the modern Chinese then current: Tōon kashaku moji, 唐音仮借文字. Since this was created probably around the same time as the $K S$, it should best be seen as another effort to formalize an already existing practice. I have not yet seen the work.

26 Udagawa Genshin 宇田川立真, Shintei zōho Oranda yakkyō 新訂增補和蘭藥鏡 (n.p, not before 1828).

27 Hidaka Ryōdai 日高涼臺, Oranda Yōyaku benran 和蘭用藥便覽 (Edo: Suharaya Ihachi, 1837). 
Japan. ${ }^{28}$ In studying such phonetic loans, we have to keep in mind, of course, that each language concerned in this triangle has its own phonetic structure, which also has undergone historical changes, all of this influencing to what extent current readings make past pronunciations visible. To simplify enormously, current modern Chinese $j$ - and $q$ - (pronounced as palatalized $c h$-) often correspond to words starting with $k$-; current $x$ - (pronounced as palatalized $s h$-) may correspond to $h$ - and vice-versa; $r$ - and $l$-are often interchangeable, as are, in Japanese, $f$ - and $h$-, or $j i$ and di. To recognize past "modern Chinese" in Japanese, most indicative are the endings 爾 or 兒, $-l$ or $-r$, read in MCK as $r u$ rather than SJ ${ }^{*} j i .^{29}$

A particular subgroup where words read in MCK originate from actual direct loanwords from Chinese, and are not Japanese creations, is formed by place names. They occur much more widely than in just rangaku works. They go back to early circulated Jesuit-produced maps, or Chinese and Japanese geographical works based upon such maps. ${ }^{30}$ Hence such terms as мСк Zermania 入爾馬泥亞 for Germania, or MCK Nān-Yamerrikya for 南亞墨利加. ${ }^{31}$ This common practice, together with the long-standing way of Chinese phonetic renderings for Buddhist terms, may very well have been the reason why MCK came to be used for other foreign, c.q. Dutch, loanwords as well. ${ }^{32}$

Let us see how this all works out in the 1774 Kaitai shinsho, already mentioned. ${ }^{33}$ It was a translation, or at least an interpretation, of Johann Adam Kulmus' Ontleedkundige Tafelen, itself a translation of the pre-1722 Tabulae

28 "Loan-translations" is the term he uses for what linguists usually call calques. For more calques and phonetic loanwords in Japanese itself from Dutch, see F. Vos, "Dutch Influence on the Japanese Language," Lingua 12 (1963): 341-88.

29 And in Southern Guanhua the current final -ei was often pronounced with a short -e; and here, keeping in mind that Chinese does not have voiced initials, we arrive at the pronunciation Peking for Beijing: Peking was the correct pronunciation in sixteenth-century Southern Guanhua. In Japanese, Pekin.

See for the influence of Matteo Ricci on East Asian cartography, including its later Chinese, Dutch and Japanese versions Helen Wallis, "The Influence of Father Ricci on Far Eastern Cartography," Imago Mundi 19 (1965): 38-45.

$31 \quad K s$ has MCK Arumaniya 亞爾馬泥亞 for Germany, reading in the same word 亞, C ya, as $a$ and $y a$.

32 While it can be occasionally difficult to decide whether a particular phonetic word needs a reading in modern Chinese, or whether sJ would suffice, I have rarely come across cases where a SJ reading is the only possible one. One example is in the 1866 Seiri hatsumo 生理發蒙 (tr. Shimamura Teiho 島村鼎甫 [Kyoto: Katsumura Yauemon, 1886], orig. Eerste grondbeginselen der natuurkunde van den mensch, 1855), where the last name of its original author, Douwe Lubach, is written as Ribakku 李遥, the "bakku" clearly a sJ reading only $(\mathrm{C}$ mao $)$.

33 For various aspects of the Ks, see Gabor Lukacs, Kaitai shinsho, The Single Most Famous Japanese Book of Medicine, \& Geka sōden, An Early Very Important Manuscript on Surgery 
Anatomicae, hence it is also known in MCK as Täheru Anatomii 打係縷亞那都 米. From 1826 various revised, updated translations were published by Ōtsuki Gentaku 大梘玄澤 as Chōtei Kaitai Shinsho 重訂解體新書, for which the notes to the original illustrations had been translated too, which was not the case for the $K s$. I use here an Edo edition from 1843, published by Suharaya Mohē. ${ }^{34}$

Now, what is often overlooked is that the editorial principles (hanrei 凡例) of the $K S$ and the $C K S$ are very different, despite the author of the latter blithely referring to his rewrite as constituting "the editorial principles of the old version." And, most interestingly, they differ exactly in the topics we are interested in.

Both sets of principles mention that they used the three modes of translations we already saw; the $K S$ calling them honyaku ("transposed translation"), giyaku ("semantic translation"), and chokuyaku ("direct translation"). Sugita Genpaku means with these terms pure translation, calques, and phonetic loans, respectively. Ōtsuki Gentaku lists the three divisions as chokuyaku-giyaku—taiyaku, thus changing the referent of chokuyaku from phonetic to pure translation, and he revises the example for the second mode causing it to change from a calque into a pure neologism. And indeed, Genpaku had misunderstood one Dutch word, translating kraakbeen, cartilage, as nankotsu 軟骨 ("soft bones"), on the misunderstanding that kraak means "soft" (it doesn't, it means "to crack"). But by seeing kraak=soft=nan, and been=bone=kotsu, he applies the calque principle correctly. Gentaku, perhaps realizing Genpaku's mistake, replaces it with another example, which however is a pure neologism: shinkei 神經 for Dutch zenuw, nerve ("divine-fluid flow,") ${ }^{35}$ also a word still in current Japanese and Chinese use. But that is not the meaning of zenuw, the Dutch word for "nerve," and hence, it is not a calque.

What is immediately transparent when comparing the $K S$ and the $c K S$ is that the $C K S$ uses a quite different set of characters to render names or terms. The author's name, Johann Adam Kulmus, is transcribed as 玉函亞秧鳩盧模斯 (C Yuhan Yadan Jiulumosi) rather than 與般亞單閲兒武思 (C Yuban Yadan

(Utrecht: Hes \& De Graaf, 2008), who gives an account of how the work came into being, and also places the content of the work in an Asian context, 170-71.

34 A close study of the $c K S$, by Sugimoto Tsutomu 杉本つとむ, Edo jidai Rangogaku no seiritsu to sono tenkai 江戶時代蘭語学の成立とその展開, 5 vols. (Tokyo: Waseda Daigaku Shuppanbu, 1976-1982), 5: 227-55, compares in detail the editorial principles of the $K S$ with those of the $c K S$. To Sugimoto, Ötsuki comes across as rather pedantic in some of his revisions. The $C K S$ replaces many phonetic loans with existing or new Chinese terms. See Mieko Macé, "Le chinois classique comme moyen d'accès à la modernité," Daruma 4 (1998): 79-103.

35 Both words are still in current Japanese and Chinese use. Earlier works on Dutch medicine used a MCK phonetic loan for zenuw: senyū (or sēnyū) 泄奴. 
Que'erwusi). The MCK reading for either is Yohan Atan Kyurumusu, while a sJ pronunciation would have been something like *Gyokuhan Atan Ketsujimushi. In this, the $c K s$ seems more consistent (the $K s$ mixes some characters better read as Japanese一般 J han reads better than C ban, 武 J $m u$ better than C wu), but the $K s$ uses a better character er 兒 for $-l$, rather than 盧C lu. Other changes seem superfluous: 與 and 玉, 單 and 姍, 思 and 斯 are homonyms. "Our" author Gorter, read MCK Koiteru in both, is changed from $K S$ 故意的爾 (C Guyider) to 歌乙的盧 (C Geyidelu), with both versions differing from the (better) form we encountered above.

Gentaku in his editorial principles claims that his pronunciations are based on Hangzhou speech - and indeed, as we saw, he had gone to Nagasaki to confer with Chinese speakers there. The choice of Hangzhou pronunciation by itself seems idiosyncratic; that never was an established dialect in Nagasaki, and moreover, Southern Guanhua was in general use. However, some of Kanzan's vocabularies are said to be based upon the Hangzhou dialect; perhaps Hangzhou, close to Nanjing, stands for Southern Guanhua after all.

Sakai Kazuko has listed all phonetic transliteration examples in the $K S$ and the $c k s .{ }^{36}$ Certainly many characters are used similarly in the two works, such as 東 for ton, 達 for $d a$, 的 for $t e$, 百 for $p e$, 列 for $r e$, all which are common in other works as well, and clearly point to modern Chinese pronunciations (dong, da, de, bai, lie instead of sj *tō, *tatsu, *teki, *haku, ${ }^{*}$ retsu). There are also systematic improvements: the $K s$ writes all Latin -us name endings somewhat surprisingly as -tosu 都私, while the $c K S$ gives the much better - usu 鳥斯. But there are other less defensible changes: almost all final endings $-n$ are changed into a final $-n g$, which usually is further from Dutch pronunciation.

Sakai also raises the hypothesis that in both the $K S$ and $c K s$ first the Japanese approximation of Dutch was decided upon, and that appropriate Chinese characters were chosen later. I would suggest that this is only true for the $C K S$, not for the $K S$; and it is especially because of the final $-r$ or $-l$ that I think this. In the $K s$, the typical MCK character er 兒 or 爾 is used for final -r or -l. Their Chinese pronunciation approximates Dutch, even if they are necessarily transcribed as -ru in Japanese katakana. In the $c k s$ however, the 兒 or 爾 disappear, and are replaced by another character altogether, pronounced in Chinese $l u$ 蘆, to approximate that Japanese $r u$. Thus that Chinese character was chosen not to conform with Dutch, but to conform with Japanese.

36 Sakai Kazuko 酒井和子, “Kanji ni yoru gaikoku'on no onyakuhō: 'Kaitai shinsho' to 'Chōtei Kaitai shinsho' 漢字による外国音の音訳法-「解体新書」と「重訂解体 新書 」, Tōkyō kokusai daigaku ronsō Kyōyō gakubu-hen 東京国際大学論叢教養学部 編 49 (1994): 69-83. 
I cannot but ask one more question which to the best of my knowledge has never been posed. Why were calques so often used by the Japanese for translating Dutch, but less so for translating Latin or later English? The reason is, I think, simple: Dutch had undergone a similar movement in the sixteenth and seventeenth centuries of creating easy-to-understand compound neologisms to replace Latin and Greek scientific terms, unlike English. ${ }^{37}$ New vocabularies made of such compounds are the norm in many fields such as mathematics, physics, chemistry, geography, botany, and zoology: indeed, the names of those disciplines themselves indicate that: wis-kunde, natuur-kunde, scheikunde, aard-kunde, plant-kunde and dier-kunde. The principle is the same, and accounts for the fact that many scientific terms, so complicated in English, are easy to understand in Dutch, Chinese, or Japanese. It is this tendency which, to take a random example, allows a modern author to make such new compound words as kegeloproer ("bowling brawl.") 38

The use of Chinese in phonetic loans from Dutch or other Western languages can be linked to, and might have derived from, earlier ways of using particular Chinese characters to phonetically correspond to Sanskrit syllables, such as 佛陀 C Fotuo, for Buddha. Genpaku himself referred to the way Buddhist monks had translated from Sanskrit, and indeed, Buddhist sutras are still read in ondoku 音讀, that is, using Japanese approximations of early Chinese pronunciations meant to approximate the Sanskrit; such readings are often different from the common sJ. Thus, anyone in Japan would have been familiar with those characters, some common, some mostly encountered only in this context. Some standardization had taken place for such sets of characters, and in Tokugawa times there existed a lively field of siddham studies on how best to pronounce Sanskrit phrases in order to make mantras magically effective. ${ }^{39}$

37 One reads often that the Flemish polymath Simon Stevin (1540-1620) stands behind this movement, and indeed, he created neologisms in many fields. Chinese readers may like the fact that he sought to prove the superiority of Dutch by pointing out the large number of single syllables with complete meanings. See especially E.J. Dijksterhuis, Simon Stevin ('s-Gravenhage: M. Nijhoff, 1943), 298-320. But the movement was larger, and e.g., Dodoens and his Cruydt-boeck already was another example of the same movement. Cf. note 3 .

38 Albert Hoffstädt, "Menig Heer Wankelt," in De Vriendschap die Ons Bindt: Amicitia 1768 2018, ed. Jan van Rijckevorsel and Paul Menken (Leiden: Amicitia, 2018), 25.

39 Zürcher has argued for early standardization; see E. Zürcher, The Buddhist Conquest of China: The Spread and Adaptation of Buddhism in Early Medieval China (Leiden: Brill, 1959), 40. An eighth-century table I consulted exists in the Buddhist Canon: the Yujie jingangding jingshi zimu pin 瑜伽金剛頂經釋字母品 by Amoghavajra (T. 880). For a historical overview of Chinese and Japanese studies on siddham, see R. H. van Gulik, Siddham: An Essay on the History of Sanskrit Studies in China and Japan (Nagpur: International Academy of Indian Culture, 1956). 
There generally existed two such tables, called southern and central. But while they certainly have characters we encounter in Dutch transcriptions too, such as 都 for $t u$, there does not seem to be much overlap; e.g., the $u$, which we frequently encounter as 烏 to render Dutch, is 甌 in the southern, and 塢 in the central system. ${ }^{40}$ Similar transliteration tables, transmitted through Korea, were also in use for man'yōgana 万葉仮名, a system whereby particular characters were used to write Japanese names phonetically in early texts. ${ }^{41}$ But also in this case it must be said that when we look at the actual characters concerned, there seems to have been no direct influence: while 烏 for $u$, or 泥 for $n i$ is common both in Tokugawa medical texts and man'yoggana, the ubiquitous MCK 亞 for $a / y a$ or 的 for de/te are not encountered in man'yogana-and certainly there is no provision for $-r$ 爾/兒. In any case, the references to Buddhist precedents occasionally mentioned by Sorai or other rangaku scholars usually refer to the earlier translation movement of the sutras, not to contemporary siddham studies.

Thus, we may tentatively conclude that to render foreign loanwords, the earlier Buddhist and Jesuit practices may have induced the Dutch specialists to use modern Chinese transliterations for rendering Dutch or Latin as well, even if they differed in the actual characters used.

Let us finish this article by looking once more at an example of the complex ways kaeriten and furigana, and Dutch and Chinese could play together, by noting how a kind of kanbun practice could be used to translate Dutch sentences as well. I use an example from an 1856 Dutch textbook Rangaku hitori annai 蘭學獨案内..$^{42}$ First, we have in Dutch, written vertically: Hij is de ergste man, die ik ooit gezien heb. (which means: He is the worst man, that I ever saw [=seen have]). This sentence has two lines in small characters to its left. The inner one reads: Karewa aru Ø mottomoashiki hitode tokoronohitodewa ware imamade mi taru (with the parts written with Chinese characters bolded, and the remainder written in katakana; and to correspond one-by-one to the Dutch words, with all syllables corresponding to one Dutch word spelled together). The outer line to the very left gives numbers, in Chinese characters, just before the words in the inner left line start: $19 \emptyset_{7} 862345$. Reordered, this finally gives us the Japanese reading: Karewa ware imamade mi taru mottomoashiki

\footnotetext{
40 Mabuchi Kazuo 馬湔和夫, Shittanshō no kenkyū 悉量章の㸴究 (Tokyo: Bensei Shuppan, 2006), 50-51.

41 John R. Bentley, "The Origin of man'yōgana," Bulletin of the School of Oriental and African Studies, 64.1 (2001): 59-73.

42 Kano Ryō 可野亮, Rangaku hitori annai (Edo: Izumi Hanbee, 1856). Example taken from Sugimoto, Kokugogaku to Rangogaku, 382 .
} 
hitode aru, or in more proper punctuation, Kare wa ware ima made mitaru mottomo ashiki hito de aru, which is more or less a proper Japanese translation corresponding to the Dutch. Of course, in a festive work such as this, perhaps I should have changed ashiki into yoki, "good." But as scholars, librarians, and editors know, one always has to stay true to the primary sources. 